\title{
The Influence of Online Game on The Learners' Arabic Vocabulary Achievement
}

\author{
Helmi Kamal* \\ Arabic Language and Literature Study Program Institut Agama Islam Negeri Palopo, Indonesia
}

Article History:

Received : November 20, 2020

Revised : December 26, 2020

Accepted : January 28, 2021

Published : June 01, 2021

\section{Keywords:}

Classroom Action Research; Online Game; Learners' Vocabulary Mastery; Teaching Arabic Vocabulary

*Correspondence Address: helmikamal@iainpalopo.ac.id

\begin{abstract}
Online game is suggested as a medium that can encourage learners' acquisition of Arabic vocabulary. This research aimed to find out the learners' vocabulary achievement before applying online game to the learners and to describe the usage of online game in improving learners' vocabulary achievement effectively. This research used Classroom Action Research. There were 30 learners involved. Teaching processes consisted of two-cycle. Interviews, observation, tests, and documentation were the instruments of this research. The results of the tests were analyzed by using SPSS 20; the results of the interview and observation were analyzed qualitatively. The author found that online game improves learners' vocabulary. The average score in cycle I was better than the average score in cycle II. The Pretest results in cycle I showed the greatest score obtained by the learners was 76. While in the Post test of the cycle I, the greatest score obtained by the learner was 90 . Whereas in cycle II, the greatest score obtained by the learners was 100 . Based on the observation, the learners were more excited on studying and focus on finishing their task; the learners could understand well the subject was given, and the learners were more enthusiastic in memorizing vocabulary. The author had successfully provided a new experience for learners who always learn conventionally by involving into the appealing and interactive online game-based learning atmosphere. The author hoped this research could be guidance for the effectuality of the next Arabic language learning through the online game in the class.
\end{abstract}

\section{Introduction}

Vocabulary is one of the essential language aspects ${ }^{1}$ and it is basic aspect in language that has to be mastered. Lack of vocabulary might cause inability to communicate well in the target language for the learners. In learning a foreign language, vocabulary becomes something crucial due to it involves integrated language skills. Regardless of vocabulary role in creating effective communication, learners often have

1 Noor Azli Mohamed Masrop, Hafawati Ishak, Ghazali Zainuddin, Siti Rosilawati Ramlan, Muhammad Sabri Sahrir, Harwati Hashim. "Digital Games Based Language Learning for Arabic Literacy Remedial". Creative Education, 10.12 (2019): 3213-3222. 
trouble in studying vocabulary ${ }^{2}$. There are a lot of obstacles in learning vocabulary such as individual differences in their ability, the affective components (motivation, attitudes towards vocabulary learning, worry about lack of success) or the language learning aptitude $^{3}$.

Based on a 4-week pre-observation in the tenth-grade learners of Islamic Boarding School of Palopo, it was found that some learners also admitted that they have different school backgrounds between one another. Some learners come from an Islamic school; other learners come from general school. It certainly will become a problem in the sustainability of the learning process because several students who come from general school have never studied Arabic. Meanwhile, the learners who come from Islamic school basic knowledge about Arabic. This will also affect lahjah (learners' pronunciation) in reading Arabic text ${ }^{4}$. Besides, conventional approach is still used in their teaching and learning activity which the teachers become dominated in learning activities (teacher-centred learning activities), and the learning guidance is measured from the completion of learners working on the worksheet. Teachers tend to use the same method of delivering lesson material, so that the learning activity is less attractive to learners, as well as in language development lesson, especially in improving the ability of Arabic vocabular. The result of observation showed that learners are being lazy, sleeping on their desk, and chattering with their friend, not paying attention to the learning material. Besides, some information was obtained that the learners were unable to transfer the meaning of words and difficult to spell the words correctly and properly.

The teaching-learning atmosphere has to be outgoing and the use of conventional techniques and instructional devices should be changed ${ }^{5}$. The learners have to achieve the learning processes. To overcome this problem, the teacher or the facilitator applies distinct kinds of teaching techniques, methods, materials, aids, media, and strategies. If the teacher applies merely an oral explanation or lecture method, effective learning will not go well. In the previous years, educators issued instructions and sustained learning

\footnotetext{
${ }^{2}$ Serkan Çelik and Veli Toptaş, "Vocabulary Learning Strategy Use of Turkish EFL Learners"', Procedia Social and Behavioral Sciences 3, (2010): 62-71.

3 Visnja Pavičić Takač, Vocabulary Learning Strategies and Foreign Language Acquisition (Clevedon: Multilingual Matters, 2008), 12-13.

${ }^{4}$ Syukra Vadhillah, "Problematika Pembelajaran Bahasa Arab Di Madrasah Aliyah Negeri (MAN) Batu Mandi Tilatang Kamang" Arabia: Jurnal Pendidikan Bahasa Arab vol. 8, no. 1 (2016): 47-69.

5 Shikha Kapur, Teaching Aids: Non-Conventional and Modern, accessed 10 July, 2020. http://www.researchgate.net/publication/327971438_Teaching_Aids_Nonconventional_and_Modern.
} 
processes by using many forms of media. The examples of instructional media are conventional ways of providing instructions (whiteboards, books, LCD, and pictures), mass media used for education (magazine, movie, radio, advertisement, and television), and recent electronic devices (laptop, video, smartphone, and tablet).

Due to the technology development, educators need to integrate technology in Arabic language teaching for some reasons ${ }^{6}$. First, technological innovations are possible ways to enhance learners' attentiveness and motivation in Arabic learning ${ }^{7}$. Second, through online learning, the process of teaching language can run effectively, and money and time are not wasted ${ }^{8}$. Third, Arabic online learning used extensively brought through learners to utilize various learning strategies to reach the learning and teaching objectives of the Arabic language course ${ }^{9}$. Online learning assists educators with a restricted supply of learning materials ${ }^{10}$. Therefore, the author was interested in researching online game in teaching vocabulary although some researchers found that there are also several students do not understand about the utility and the easiness of use of playing online game at school ${ }^{11}$.

Online games are learning by applying games through the internet ${ }^{12}$. By using the online game in the teaching and learning process, the learners can develop their critical thinking skills ${ }^{13}$. Online games create an interactive and motivating context where learners can handily and subconsciously disseminate their information, and also due to their needs and duties during playing. Therefore, online games are useful in vocabulary

${ }^{6}$ Khairun Nisaa Mohd, Airil Haimi Mohd Adnan, Ahmad Ariffuddin Yusof, Muhamad Khairul Ahmad."Teaching Arabic Language to Malaysian University Learners Using Education Technologies Based on Education 4.0 Principles." Paper presented at International Invention, Innovative \& Creative (InIIC) Conference, Series 2 at Palace of the Golden Horses, Kuala Lumpur, Malaysia, (2019): 38-51.

7 Azkia Muharom Albantani and Imam Fitri Rahmadi, "Mobile Devices for Arabic Learning in Junior High Schools: The Teachers' Perspective.," Jurnal Al Bayan: Jurnal Jurusan Pendidikan Bahasa Arab 12. 2, (2020): 191-207.

${ }^{8}$ Susan Y.H. Sun, “Learner Perspectives on Fully Online Language Learning,” Distance Education 35.1, (2014): 18-42.

${ }^{9}$ Abdallah Alasraj and Hael Alharbi, "The Effectiveness of Blended Learning in Teaching Arabic as a Second Language," International Journal of Research in Humanities and Social Studies 1, no. 1 (2014): $13-17$.

${ }^{10}$ UNICEF, Children in a Digital World, (New York: Division of Communication, 2017), 1.

${ }^{11}$ Mark Anthony Camilleri and Adriana Camilleri, "The Students' Perceptions of Digital GameBased Learning," Proceedings of the 11th European Conference on Games Based Learning, FH Joanneum University of Applied Science, Graz, Austria, (October 2017).

${ }^{12}$ M. Hamizul and Nik Mohd Rahimi, "Design and Development of Arabic Online Games - A Conceptual Paper," Procedia - Social and Behavioral Sciences, no. 174 (2015): 1428-33.

${ }^{13}$ Derya Sahhusyeinoglu, "Educational Games for Developing Critical Thinking Skills: Pre-Service English Language Teachers' Views," ERIC 32 (2007): 266-73. 
acquisition $^{14}$. Online game enlarges learner's perception, concentration, immersion and knowledge progress ${ }^{15}$. It is useful for studying vocabulary in a language class, and it motivates learners for studying. The online game can make teachers work easier, and learners may access to diverse type of vocabularies ${ }^{16}$. There are several previous researchers talked about online game such as Azizi and Subiyanto, ${ }^{17}$ Belkouche, ${ }^{18}$ Prensky, ${ }^{19}$ Zou et.al, ${ }^{20}$ online game for children with dyslexia (Vasalou et.al), ${ }^{21}$ scrabble game media for learning Arabic (Saputra). ${ }^{22}$

\section{Method}

Classroom action research was used in this research. Classroom action research is small-scale classroom research carried out by teachers and it aimed at enhancing learning outcomes. Teachers used classroom action research to solve a problem or an issue in the classroom $^{23}$. The procedure of Classroom Action Research is repeated cycle's form ${ }^{24}$. There were four common stages of classroom action research, namely, planning, implementation or action, observation, and reflection. The design of this research referred to the planning of how to teach vocabulary well and it is about using the online game in vocabulary learning. The participant of the research was the tenth-graders of Islamic Boarding School of Palopo in the academic year of 2018/2019. There were 35

\footnotetext{
${ }^{14}$ Hamid Ashraf, Fateme Ghanei Motlagh, and Maryam Salami, "The Impact of Online Games on Learning English Vocabulary by Iranian (Low-intermediate) EFL Learners." Procedia - Social and Behavioral Sciences, 9 (2014): 286-291.

${ }^{15}$ Muhammad Sabri Sahrir and Ghazali Yusri, "Online Games for Teaching and Learning Arabic," Gema Online Journal of Language Studies, 12.3 (2012): 961-77.

16 Mahmut Kayaalti, "A Literature Review on the Impact of Online Games in Learning Vocabulary,” International Journal of Scientific and Research Publicatios, 8.2 (2018): 312-17.

17 Annas Nur Azizi and Subiyanto, "Digital Game-Based Learning in Arabic Language Learning and its effects on Students' Academic Performance," Paper presented at International Conference on Indonesian Technical Vocational Education and Association, (2018).

${ }^{18}$ Boumediene Belkhouche, Nafla Saeed Al Darei, et.al, "Learning Arabic with Games." Paper presented at Computer Games Multimedia and Allied Technology Conference, Singapore, (2014).

${ }^{19}$ Marc Prensky, Digital Game-Based Learning (New York: Paragon House, 2001).

${ }^{20}$ Di Zou, Yan Huang, and Haoran Xie, "Digital Game-Based Vocabulary Learning: Where Are We and Where Are We Going?" Computer Assisted Language Learning, 32 (2019): 1-27.

${ }^{21}$ Asimina Vasaloua, Rilla Khaled, Wayne Holmes, and Daniel Gooch. "Digital Games-Based Learning for Children with Dyslexia: A Social Constructivist Perspective on Engagement and Learning during Group Game-Play." Computers \& Education, 114 (2017): 175-192.

${ }^{22}$ Firman Nur Saputra, Aplikasi Game Scrabble sebagai Media Pembelajaran Bahasa Arab Menggunakan Metode Finite State, (Malang: UIN Maulana Malik Ibrahim Malang, 2015).

${ }^{23}$ John W. Creswell, Educational Research: Planning, Conducting, and Evaluating Quantitative and Qualitative Research. 4th ed (Boston: Pearson Education, 2012), 120.

${ }^{24}$ Andri Donal, "Improving the ESP Learners' Vocabulary by Using Pictures in Agribusiness Study Program of the University of Pasir Pengaraian," Edu Research: Jurnal Pendidikan, 1.1 (2012): 77-95.
} 
learners. There were 2 males and 33 females. Their ages were around 19 years old. The author chose these learners because their vocabulary needs an improvement.

The author used interview, observation, test, and documentation as the instruments of the research. The author used a structural interview. In learning vocabulary process, the author observed to know the learners' interest and activeness during teaching and learning process. In this case, the author investigated directly in school. The test consisted of 30 questions. In part A, the learners translated the words into Indonesian which consisted of 10 questions. In part B, multiple-choice consisted of 10 questions and in part $\mathrm{C}$, there were 10 matching the words with the pictures questions. To collect the data, the author did some steps. The steps are mentioned below: (1) The author asked some questions to the learners to get some primarily information about the learners. (2) The author observed the learners' condition before implementing online game and to see the learners' behaviour during the teaching and learning processes. (3) The author tested the learners. Their purpose was to know the learners' achievement on vocabulary and to know whether online game can develop the learners' capability. (4) The author taught the learners by using online game. Every cycle in the classroom consisted of planning, implementation/action, observation, and reflection.

The data from observation and interview were analyzed qualitatively. The data were taken from the test analyzed by using the following steps: (1) The author tried to get the score per action within one cycle. It was used to know how well learners' score as a whole on vocabulary skill. The raw score for the correct answer was 1 . The raw score for the incorrect answer was 0. (2) Raw scores were converted to a set of core of maximum of 100, using the following formula:

$$
\text { Score }=\frac{\text { The total of the students correct answer }}{\text { The total of items }} X 100
$$

(3) The author converted the score of the learners. (4) The author classified the score of the learners into rubric score by Brown. (5) The author tried to get the class percentage which passed the criteria of minimal mastery level considering Arabic subject gains score 76 which was adapted from the school agreement. (6) To analyze the objective test from learners, the author used Statistical Produce and Service Solution (SPSS) version 20 for windows. 


\section{Result and Discussion}

How was the learners' vocabulary achievement before the vocabulary improvement activity?

Before implementing CAR, the author interviewed the learners in the first semester. The learners' answer were: 60\% learners like studying English and 40\% learners dislike studying Arabic. They thought that Arabic was difficult because they did not know the averageing and the teacher gave them the monotonous technique in learning Arabic. When the author gave them some vocabularies taken from learners' book, then the author asked them to memorize the whole vocabulary. Besides, the author also asked them to memorize some conversation that makes them bored and they easily forobtained what they had memorized because the vocabularies were never recalled.

In the initial test, the average score was 65.97. 4 learners obtained score " 76 " and passed minimum completeness criteria (>76), 8 learners obtained score "73", 6 learners obtained score "70", 4 learners obtained score "67", 1 learner obtained the score of 63, 2 learners obtained score "60", 1 learner obtained score "53", 1 learner obtained score "47" and 3 learners obtained score "40." The value of learner's learning outcomes in initial test was grouped into five categories, the learning outcomes of learners are presented as follows:

Table 1. The Rate Percentage of Learners' Score of Initial test

\begin{tabular}{|c|c|c|c|}
\hline Classification & Score & Frequency & Percentage \\
\hline Excellent & $90-100$ & - & - \\
\hline Good & $80-89$ & - & - \\
\hline Adequate & $70-79$ & 18 & $60 \%$ \\
\hline Inadequate & $60-69$ & 7 & $23 \%$ \\
\hline Poor & Below 60 & 5 & $\begin{array}{l}17 \% \\
100 \%\end{array}$ \\
\hline
\end{tabular}

The table 1 showed that the learners' score at the pretest in cycle I there was no one obtained excellent and good classification, 18 learners (60\%) obtained adequate classification, 7 learners (23\%) obtained inadequate classification and 5 learners (17\%) obtained poor classification. Based on the author's observation, most of the learners taking part in this research did not have high learning motivation as the author expected. 
Lack of learning motivation assuredly has a negative impact on learners' language prowess $^{25}$.

\section{How did the online game improve vocabulary achievement more effectively to the tenth grade learners of Islamic Boarding School of Palopo?}

The action conducted in two cycles that covered four meetings. The obstruction and failure found in cycle 1 and then looked for the solution and applied to the next cycle. The result of the research could be reported as follows:

\section{Cycle 1}

There were two meetings in cycle 1 . Time allocation for each meeting was 80 minutes. The author modified the steps of teaching process in the first and second meeting. The author found that the learners' score was better than the initial test. Twentyone learners had reached minimal completeness criteria (> 76). 2 learners obtained score “90", three learners obtained score "87", three learners obtained score "83", nine learners obtained score "80", four learners obtained score "76", one learner obtained score "73", two learners obtained score "70", one learner obtained score "67", one learner obtained score " 66 ", one learner obtained score " 63 " and three learners obtained score "60." The results of learners' achievement in cycle one were classified into five categories as follows:

Table 2. The Rate Percentage of the Learners' Achievement in Cycle 1

\begin{tabular}{|c|c|c|c|}
\hline Classification & Score & Frequency & Percentage \\
\hline Excellent & $90-100$ & 2 & $7 \%$ \\
\hline Good & $80-89$ & 15 & $50 \%$ \\
\hline Adequate & $70-79$ & 7 & $23 \%$ \\
\hline Inadequate & $60-69$ & 6 & $20 \%$ \\
\hline \multirow[t]{2}{*}{ Failing } & Below 60 & - & - \\
\hline & & & $100 \%$ \\
\hline
\end{tabular}

The table 2 showed that the post test score in cycle I there were two learners (7\%) obtained excellent classification, 15 learners (50\%) obtained good classification, seven learners $(23 \%)$ obtained adequate classification, six learners $(20 \%)$ obtained inadequate classification, and the good thing that there was no one learner obtained failing classification. The author also observed the learners' activeness in learning processes. She found that there were $30 \%$ learners very active in the learning process, $43 \%$ learners were active, $27 \%$ learners were less active to join the study, and nobody was inactive.

${ }^{25} \mathrm{Wu}$ and Lin-Fang, “A Study of Factors Affecting College Learners' Use of ESL Vocabulary Jurnal Al Bayan: Jurnal Jurusan Pendidikan Bahasa Arab, 13 (1): 16-31 (2021)| 22 
The implementation of learning by using the online game in the cycle I could be said to be quite good, but there were still some obstacles. The constraints were some learners still less active in the learning process, and the learners were unfocused on the author's explanation. These obstacles were caused by learners who were still uninterested in learning vocabulary. The learners' need, capacities, and skills are a good match for the demands offered by a specific activity. The learners' interest showed in an activity or an area of knowledge forecasts how much they would present to it and how they processed, understood, and thought about it. The result of this finding is similar to Hidayat (2016) who stated that in his research, the learners had not mastered any vocabulary because they did not bring an English dictionary and did not pay attention to the material explanation $^{26}$.

Cycle 2

There were two meetings in cycle 2 . In this cycle, the steps of teaching vocabulary were different from cycle 1. In this cycle, the learners competed in the group to check whether the learners mastered the materials. The author asked every group to raise their hand if they knew the answer. In which, every group had to say the words, the meanings and the class of the word directly.

The author found that the learners' score was better than the post test in cycle I, 29 learners had reached minimal completeness criteria (> 76), and only one learner had not reached it yet because she obtained score "73". The results of learners' achievement in cycle 2 were as follows:

Table 3. The Rate Percentage of Learners' Achievement in Cycle 2

\begin{tabular}{llll}
\hline \multicolumn{1}{c}{ Classification } & \multicolumn{1}{c}{ Score } & Frequency & Percentage \\
\hline Excellent & $90-100$ & 13 & $43 \%$ \\
Good & $80-89$ & 12 & $40 \%$ \\
Adequate & $70-79$ & 5 & $17 \%$ \\
Inadequate & $60-69$ & - & - \\
Poor & Below 60 & - & - \\
& & & $100 \%$ \\
\hline
\end{tabular}

The table 3 showed that the learners' score of the post test in cycle II. There were 13 learners $(43 \%)$ obtained excellent classification, 12 learners (40\%) obtained good

\footnotetext{
Learning Strategies.”," International Journal of Humanities and Social Science, 3.19 (2013): 202-228.

${ }^{26}$ Nur Hidayat, "Improving Learners' Vocabulary Achievement through Word Game," Journal of Educators Society, 1.2 (2016): 95-104.
} 
classification, five learners (17\%) obtained adequate classification, and there was no one learner obtained inadequate and poor classification.

The author observed the learners in cycle II. The observation phase in cycle II was recorded on the participation of activeness in each learner towards the process of learning English. The learners' activity was obtained from observation sheets in the meeting recorded in each cycle; the observation sheet was used to determine the participation or motivation of learners in learning vocabulary by using the online game.

The author found that the learners' were more active than in cycle I, there were $40 \%$ learners very active in the learning process, $47 \%$ learners were active to study, $13 \%$ learners were less active to study, and every student was active in class. It can be concluded that most of the learners were active in the learning process.

The average score of the learners' achievement in vocabulary showed the comparison of all averages scores achieved from pre test, cycle 1 and cycle 2 .

Table 4. Comparison of the Learners' Vocabulary Test Results

\begin{tabular}{lll}
\hline \multicolumn{1}{r}{ Test Types } & \multicolumn{1}{c}{ Average Scores } & \multicolumn{1}{c}{ Classification } \\
\hline Pre test & 65.97 & Inadequate \\
Cycle 1 & 76.77 & Adequate \\
Cycle 2 & 87.77 & Good \\
\hline
\end{tabular}

Based on the table 4, we can see that there was an improvement since initial test up to cycle 2 . The difference from the initial test to the final test in cycle 1 was 10.8 . On the other hand, the difference between final test in cycle 1 and cycle 2 was 11 .

Vocabulary knowledge differs among learners. There are learners who have rich and poor vocabulary. Learners have a restricted vocabulary due to some factors namely vocabulary is not boosted at home because their mother tongue does not provide them of opportunities for exercise English repeatedly. Learners get less experience outside of their home, and English is their second language ${ }^{27}$. There are several factors which cause difficulties, such as motivation, attitudes, language anxiety, self-confidence, language ability, and family ${ }^{28}$. Motivation is one of the crucial factors which improve learners' language learning acquisition.

\footnotetext{
${ }^{27}$ Ilhem Darfilal, The Effectiveness of Using Language Games in Teaching Vocabulary the Case of Third Year Middle School Learners, accessed 23 April, 2020. http://pdfs.semanticscholar.org/9779/d73cf5485bdd952faaa9795edc5b66fa177f.pdf, 2017.

${ }_{28}^{28}$ Rebecca L. Oxford, Language Learning Strategies. What Every Teacher Should Know (Boston: Heinle \& Publisher, 1990), 92.
} 
A learner can achieve plentiful vocabulary with the help of vocabulary learning strategies. A factor affects learnerps' vocabulary mastery, namely in teaching vocabulary, teachers should afford learners an opportunity to encounter words recurrently and in more than one context $\mathrm{t}^{29}$. One of the most important things in studying vocabulary is to keep words in mind, or more exactly to save words in memory. In studying language, memorizing vocabulary takes a vital role ${ }^{30}$.

Burguillo, ${ }^{31}$ Chen et al., ${ }^{32}$ Dickey, ${ }^{33}$ Harris \& Reid, ${ }^{34}$ John,,${ }^{35}$ Miller et al, ${ }^{36}$ Sahrir $\&$ Zainuddin ${ }^{37}$ explained the same benefits of learning vocabulary by using online game included developing learning motivation, improving learners' acquisition in language, and increasing learner's activity. Children, teenagers, and adults show a high and positive level of acceptance toward online game and allow them to use online game as a medium of teaching and learning ${ }^{38}$.

Based on the observation, the learners focused on finishing the task, the learners could understand well the subject was given, the learners were more enthusiastic in memorizing vocabulary by using word building, and the learners were more cooperative in their group when they were given activities. This fact was suitable with the advantages of learning by using online game for encouraging the learners to study seriously. These

\footnotetext{
${ }^{29}$ Linda Diamond and Linda Guthohn, Teaching Vocabulary, accessed 25 June, 2020. http://www.readingrockets.org/teaching vocabulary, 2006.

${ }^{30} \mathrm{Wu}$ and Lin-Fang, "A Study of Factors Affecting College Learners' Use of ESL Vocabulary Learning Strategies." International Journal of Humanities and Social Science, 3.19 (2013): 202-208.

${ }^{31}$ Juan C. Burguillo, "Using Game Theory and Competition-Based Learning to Stimulate Learner Motivation and Performance." Computers \& Education, 55.2 (2010), 566-575.

32 Menghua Chen et al., "The Effectiveness of Digital Game-Based Vocabulary Learning: A Framework-Based View of Meta-Analysis.” British Journal of Educational Technology, 49.1 (2016): 6977.

33 Michele Dickey, "Murder on Grimm Isle: The Impact of Game Narrative Design in an Educational Game Based Learning Environment.” British Journal of Educational Technology, 42.3 (2010): 456-469.

34 Kristen Harris and Denise T. Reid, "The Influence of Virtual Reality Play on Children's Motivation." Canadian Journal of Occupational Therapy, 72.1 (2005): 21-30.

35 Alex John, Vocabulary Learning in Digital-Game Based Learning Using Sega Genesis Video Games. Paper presented at ICTTE FKIP, UNS, (2015): 837.

36 Miller, Leslie M, C.-I. Chang, Shu Wang, Margaret E. Beier and Yvonne Klisch, "Learning and Motivational Impacts of a Multimedia Science Game." Computers \& Education, 57.1 (2011): 1425-1433.

${ }^{37}$ Muhammad Sabri Sahrir and Nurkhamimi Zainuddin. Online Games For Teaching And Learning Arabic: Theories And Practice: The Design and Development of Online Digital Games in Language Teaching and Learning. (London, UK: LAP LAMBERT Academic Publishing, 2016).

38 Muhammad Sabri Sahrir and Nor Aziah Alias, "Study on Malaysian Language Learners" Perception towards Learning Arabic via Online Games." GEMA Online ${ }^{\mathrm{TM}}$ Journal of Language Studies, 11.3 (2011): 125-143.
} 
activities are enjoyable, innovative and interesting enough to keep the learners engaged with words. ${ }^{3940}$

As an alternative to worksheets, the teachers can use games as a less stressful way for learners to demonstrate their knowledge, skill and comprehending of a topic. Being less stressed will help learners to have a more positive perception of their learning environment and give a true indication of their own learning. Besides, by using games, learners can refresh when they are bored with teacher-centered, textbook and examination $^{41}$. Learners and teachers give highly positive response about the role of games in making their language better ${ }^{42}$. Games received a high and positive level of acceptance among users especially children and teenagers as well as adults that allow them to use it as a medium for teaching and learning. To conclude, the author asserted that online game can be both educational and entertaining. It gives learners plenty of opportunity to play while working. They can study everywhere and every time $e^{43}$.

The limitations of this research are in accordance with Masita ${ }^{44}$, Albahtani and Rahmadi $^{45}$, and Vasbieva et al., ${ }^{46}$ that the internet connection was unstable, some learners were new to the online game so that they had trouble accessing the application, every learner had different duration in understanding the lesson; some learners were quickly absorbing the lesson given while the others slowly understood the lesson, and this research was just conducted in one school, so that perhaps the next research will be conducted in several schools.

${ }^{39}$ Martin Ebner and Andreas Holzinger, "Successful Implementation of User-Centered Game Based Learning in Higher Education: An Example from Civil Engineering." Computers \& Education, 49.3 (2007): 873-890.

40 Thomas W. Malone, What Makes Things Fun to Learn? A Study of Intrinsically Motivating Computer Games. Dissertation Abstracts International, 41.5-B (1980): 1955.

${ }^{41}$ Zhang Youxin, Using Games to Motivate Chinese College Learners' Interest in Learning English. Seminar paper presented to the Graduate Faculty; University of Wisconsin-Platteville, (2010): 1-24.

${ }^{42}$ Ali Al-Bulussi and Ali S.M. Al-Issa, "Playing with the Language: Investigating the Role of Communicative Games in an Arab Language Teaching System." International Journal of Instruction, 10.102 (2017): 179-198.

${ }^{43}$ Carol Anne Ochoa Alpala and Eliana Edith Roberto Flórez. "Blended Learning in the Teaching of English as a Foreign Language: An Educational Challenge". HOW Journal, 18.1 (2011): 154-168.

${ }^{44}$ Maya Masita. "Teaching Vocabulary Using Blended Learning Method.” Ethical Lingua: Journal of Language Teaching and Literature, 7.1 (2020): 128-135.

45 Azkia Muharom Albantani, Imam Fitri Rahmadi, "Mobile Devices for Arabic Learning in Junior High Schools: The Teachers' Perspective," Jurnal Al Bayan: Jurnal Jurusan Pendidikan Bahasa Arab, 12.2 (2020): 191-207. 


\section{Conclusion}

The author revealed that online game can improve the learners' vocabulary of the tenth grades students in Islamic Boarding School of Palopo. The online game was effective to be applied in learning because the learners study vocabulary actively. The learners' score evidence it that they have passed criteria of minimum mastery. In the pretest, four-learners passed criteria of minimum mastery, and the average score was 65.97. Different from the post test cycle I, which there were 21 learners passed minimum completeness criteria, and the average score was 76.77 , then their scores improved in cycle II. Twenty-nine learners passed minimal completeness criteria with the average score was 87.77. It can be concluded that the author has successfully provided a new experience for learners who used to learn conventionally by involving into the appealing and interactive online game-based learning atmosphere. Theoretically, this research is hopeful of enriching the theory of Arabic vocabulary. Practically, this research brings some benefits for the teachers, the learners and the next researcher. This research is useful for the teacher to help his/her in choosing the appropriate material in teaching vocabulary. For the learners, it is helpful to increase their Arabic vocabulary. For the next researcher, the author suggests them to research a same topic with a distinct perspective and also to facilitate the readers in applying online game in Arabic teaching. Hopefully, it will attract the reader to practice online game in their learning vocabulary. The author suggested to another next researcher that they may use or create technological tools; however, they must concern how learners' attitude is different in offline class compare to online learning.

\section{Acknowledgment}

The author thanks to the headmaster, the teachers, and the learners of Islamic Boarding School of Palopo who have participated in this research.

\section{References}

Albantani, Azkia Muharom and Imam Fitri Rahmadi. "Mobile Devices for Arabic Learning in Junior High Schools: The Teachers' Perspective." Jurnal Al Bayan: Jurnal Jurusan Pendidikan Bahasa Arab, 12.2: (2020): 191-207.

46 Dinara G. Vasbieva et.al. "Enhancement of Learners' Vocabulary Learning through a Blended Learning Approach," IEJME - Mathematics Education Journal, 11.5 (2016): 1195-1203. 
Alasraj, Abdallah and Hael Alharbi, "The Effectiveness of Blended Learning in Teaching Arabic as a Second Language." International Journal of Research in Humanities and Social Studies, 1.1 (2014): 13-17.

Alpala, Carol Anne Ochoa and Eliana Edith Roberto Flórez. "Blended Learning in the Teaching of English as a Foreign Language: An Educational Challenge". HOW Journal, 18.1 (2011): 154-168.

Al-Bulussi, Ali and Ali S.M. Al-Issa. "Playing with the Language: Investigating the Role of Communicative Games in an Arab Language Teaching System." International Journal of Instruction, 10.102 (2017): 179-198.

Ashraf, Hamid, Fateme Ghanei Motlagh., and Maryam Salami. "The Impact of Online Games on Learning English Vocabulary by Iranian (Low-intermediate) EFL Learners." Procedia - Social and Behavioral Sciences, 9 (2014): 286-291.

Azizi, Annas Nur and Subiyanto. "Digital Game-Based Learning in Arabic Language Learning and its effects on Students' Academic Performance." Paper presented at International Conference on Indonesian Technical Vocational Education and Association, 2018.

Belkhouche, Boumediene, Nafla Saeed Al Darei, et.al. "Learning Arabic with Games." Paper presented at Computer Games Multimedia and Allied Technology Conference, Singapore, 2014.

Burguillo, Juan C. "Using Game Theory and Competition-Based Learning to Stimulate Learner Motivation and Performance." Computers \& Education, 55.2 (2010): 566575.

Camilleri, Mark Anthony and Adriana Camilleri. "The Students' Perceptions of Digital Game-Based Learning." Proceedings of the 11th European Conference on Games Based Learning, FH Joanneum University of Applied Science, Graz, Austria, 2017.

Çelik, Serkan and Veli Toptaş. "Vocabulary Learning Strategy Use of Turkish EFL Learners." Procedia Social and Behavioral Sciences, 3, (2010): 62-71.

Chen, M. H., Tseng, W. T., \& Hsiao, T. Y. (2018). The effectiveness of digital game-based vocabulary learning: A framework-based view of meta-analysis. British Journal of Educational Technology, 49(1), 69-77.

Chen, M. H., Tseng, W. T., \& Hsiao, T. Y. (2018). The effectiveness of digital game-based vocabulary learning: A framework-based view of meta-analysis. British Journal of Educational Technology, 49(1), 69-77.

Chen, Menghua. Wen-Ta Tseng, and Tsung-Yuan Hsiao. "The Effectiveness of Digital Game-Based Vocabulary Learning: A Framework-Based View of Meta-Analysis." British Journal of Educational Technology, 49.1 (2016): 69-77.

Creswell, John W. Educational Research: Planning, Conducting, and Evaluating Quantitative and Qualitative Research. 4th ed. Boston: Pearson Education, 2012. 
Darfilal, Ilhem. The Effectiveness of Using Language Games in Teaching Vocabulary the Case of Third Year Middle School Learners. Accessed 23 April, 2020. http://pdfs.semanticscholar.org/9779/d73cf5485bdd952faaa9795edc5b66fa177f.pdf , 2017.

Diamond, Linda and Linda Guthohn. Teaching Vocabulary. Accessed 25 June, 2020. http://www.readingrockets.org/teaching vocabulary, 2006.

Dickey, Michele. "Murder on Grimm Isle: The Impact of Game Narrative Design in an Educational Game Based Learning Environment." British Journal of Educational Technology 42.3 (2010): 456-469.

Donal, Andri. "Improving the ESP Learners' Vocabulary by Using Pictures in Agribusiness Study Program of the University of Pasir Pengaraian." Edu Research: Jurnal Pendidikan, 1.1 (2012): 77-95.

Ebner, Martin and Andreas Holzinger. "Successful Implementation of User-Centered Game Based Learning in Higher Education: An Example from Civil Engineering." Computers \& Education, 49.3 (2007): 873-890.

Hakim, Luqman Muhammad, Akhyar, and Asrowi. "Pemanfaatan Media Pembelajaran Game Interaktif dalam Pembelajaran Kosakata Bahasa Arab." Arabi: Journal of Arabic Studies, 2.2 (2017): 156-162.

Hamizul, M and Nik Mohd Rahimi. "Design and Development of Arabic Online Games - A Conceptual Paper.” Procedia - Social and Behavioral Sciences, 174, (2015).

Harris, Kristen and Denise T. Reid. "The Influence of Virtual Reality Play on Children's Motivation." Canadian Journal of Occupational Therapy, 72.1 (2005): 21-30.

Hidayat, Nur. "Improving Learners' Vocabulary Achievement through Word Game." Journal of Educators Society, 1.2 (2016): 95-104.

John, Alex. Vocabulary Learning in Digital-Game Based Learning Using Sega Genesis Video Games. Paper presented at ICTTE FKIP, UNS, (2015): 837.

Kapur, Shikha. Teaching Aids: Non-Conventional and Modern. Accessed 10 July, 2020. http://www.researchgate.net/publication/327971438_Teaching_Aids_Nonconventi onal_and_Modern.

Kayaalt1, Mahmut. "A Literature Review on the Impact of Online Games in Learning Vocabulary. International Journal of Scientific and Research Publications, 8.2 (2018): 312-317.

Malone, Thomas W. What Makes Things Fun to Learn? A Study of Intrinsically Motivating Computer Games. Dissertation Abstracts International, 41.5-B (1980): 1955.

Masita, Maya. "Teaching Vocabulary Using Blended Learning Method.” Ethical Lingua: Journal of Language Teaching and Literature, 7.1 (2020): 128-135. 
Masrop, Noor Azli Mohamed, Hafawati Ishak, Ghazali Zainuddin, Siti Rosilawati Ramlan, Muhammad Sabri Sahrir, Harwati Hashim. "Digital Games Based Language Learning for Arabic Literacy Remedial". Creative Education, 10.12 (2019): 3213-3222.

Miller, Leslie M, C.-I. Chang, Shu Wang, Margaret E. Beier and Yvonne Klisch. "Learning and Motivational Impacts of a Multimedia Science Game." Computers \& Education, 57.1 (2011), 1425-1433.

Mohd, Khairun Nisaa, Airil Haimi Mohd Adnan, Ahmad Ariffuddin Yusof, Muhamad Khairul Ahmad. Teaching Arabic Language to Malaysian University Learners using Education Technologies based on Education 4.0 Principles. Paper presented at International Invention, Innovative \& Creative (InIIC) Conference, Series 2 at Palace of the Golden Horses, Kuala Lumpur, Malaysia, 2019, 38-51.

Muharom, Albantani Azkia and Imam Fitri Rahmadi. "Mobile Devices for Arabic Learning in Junior High Schools: The Teachers' Perspective." Jurnal Al Bayan: Jurnal Jurusan Pendidikan Bahasa Arab, 12.2 (2020): 191-207.

Nur Saputra, Firman. Aplikasi Game Scrabble sebagai Media Pembelajaran Bahasa Arab Menggunakan Metode Finite State. Malang: UIN Maulana Malik Ibrahim Malang, 2015.

Oxford, Rebecca L. Language Learning Strategies. What Every Teacher Should Know. Boston, MA: Heinle \& Publishers, 1990.

Prensky, Marc. Digital Game-Based Learning. New York: Paragon House, 2001.

Sahhusyeinoglu, Derya. "Educational Games for Developing Critical Thinking Skills: Pre-Service English Language Teachers' Views”. ERIC, 32 (2007): 266-273.

Sahrir, Muhammad Sabri and Ghazali Yusri. "Online Games for Teaching and Learning Arabic.” Gema Online Journal of Language Studies, 12.3 (2012): 961-977.

Sahrir, Muhammad Sabri and Nor Aziah Alias. "Study on Malaysian Language Learners' Perception towards Learning Arabic via Online Games." GEMA Online ${ }^{\mathrm{TM}}$ Journal of Language Studies, 11.3 (2011).

Sahrir, Muhammad Sabri and Nurkhamimi Zainuddin. Online Games For Teaching And Learning Arabic: Theories And Practice: The Design and Development of Online Digital Games in Language Teaching and Learning. London, UK: LAP LAMBERT Academic Publishing, 2016.

Sun, Susan Y.H. "Learner Perspectives on Fully Online Language Learning." Distance Education, 35.1 (2014): 18-42.

Takač, Visnja Pavičić. Vocabulary Learning Strategies and Foreign Language Acquisition. Clevedon, UK: Multilingual Matters, 2008.

UNICEF. Children in a Digital World. New York: Division of Communication, 2017. 
Vadhillah, Syukra, Alimin, and Suharman. "Problematika Pembelajaran Bahasa Arab Di Madrasah Aliyah Negeri (MAN) Batu Mandi Tilatang Kamang." Arabia: Jurnal Pendidikan Bahasa Arab, 8.1 (2016): 47-69.

Vasalou, Asimina, Rilla Khaled, Wayne Holmes, and Daniel Gooch. "Digital GamesBased Learning for Children with Dyslexia: A Social Constructivist Perspective on Engagement and Learning during Group Game-Play." Computers \& Education, 114 (2017): 175-192.

Vasbieva, Dinara G, Irina I. Klimova, Elena L. Agibalova, Natalya V. Karzhanova, and Jana Bírová. "Enhancement of Learners' Vocabulary Learning through a Blended Learning Approach.” IEJME - Mathematics Education Journal, 11.5 (2016): 1195-1203.

$\mathrm{Wu}$ and Lin-Fang. "A Study of Factors Affecting College Learners' Use of ESL Vocabulary Learning Strategies." International Journal of Humanities and Social Science, 3.19 (2013): 202-208.

Youxin, Zhang. Using Games to Motivate Chinese College Learners' Interest in Learning English. Seminar paper presented to the Graduate Faculty; University of Wisconsin-Platteville, (2010): 1-24.

Zou, Di, Yan Huang, and Haoran Xie, "Digital Game-Based Vocabulary Learning: Where Are We and Where Are We Going?" Computer Assisted Language Learning, 32 (2019), 1-27. 